\title{
Research on the Effect of Informatization on Innovation Capability
}

\author{
Xian Wang \\ School of Management \\ Guangxi University of Science and Technology \\ Liuzhou, China \\ E-mail: 610268609@qq.com
}

\author{
Shiping Guan \\ School of Management \\ Guangxi University of Science and Technology \\ Liuzhou, China
}

\author{
Guilian Liu \\ School of Management \\ Guangxi University of Science and Technology \\ Liuzhou, China
}

\begin{abstract}
Informatization construction exerts an important effect on economic and social development, and the constant improvement of the informatization level also makes a remarkable effect. In this paper, by analyzing the contents of informatization and innovation capability, structuring an evaluation index system of informatization affects innovation capability, and building efficiency regression model, and using data envelopment analysis and multiple regression analysis to analyze the indexes. Research shows: the condition of informatization development, informatization human resource and information consumption have positive impacts on the condition of patent application which is to measure the innovation capability.
\end{abstract}

Keyword -informatization; innovation capability; evaluation index; $\mathrm{DEA}$

\section{INTRODUCTION}

Informatization is an objective trend of the economic and social developmen in the world. It is also an important sign that weighs the modernization of a country and region. With the improvement of the informatization, social economic activities take place fundamental reform. Meanwhile, it also exerts an important influence on innovation activities' efficiency and effectiveness. Our country's informatization level advances in a rapid speed, but there is still a gap compared with developed countries. And the capability of independent innovation is relatively weaker. The "double dilemma" fact that lack of independent innovation and the lower informatization level to a certain extent have affected the sustained and rapid growth of China's economy. It is a problem to be solved that how to utilize informatization to enhance technology innovation capability.

At present, the research on informatization mainly focus on information level measure and the relation of information level and economic growth, but the research on the relation of informatization and innovation capability is not enough. Besides, most research on the relation of informatization and innovation capability focus on microcosmic field, however, the research from macroscopic field is little. Given this, this paper explore the effect of informatization on innovation capability through constructing the evaluation index system and evaluation model. And then we can provide theory reference which enhance independent innovation capability and promote our country's informatization construction.

\section{CONSTRUCTION OF EVAluAtion INDEX S YSTEM}

\section{A. Informatization Index}

According to the twenty "national informatization index" which is published on national informatization index working conference in 2001, and the research results conducted by International Statistical Information Center of National Bureau of Statistics China, and combined with the views of related researchers, the paper chooses the most typical four indexes to measuring the informatization level. And the information environment is divided into two aspects of hard and soft information environment. The hard information environment is the material basis for informatization construction, and it consists of informatization development environment and informatization human resource environment. The soft information environment corresponds with hard information environment. It is the internalization of hard information environment and consists of information consumption environment and the popularization and application of information technology. Based on the analysis of the above, informatization construction can enhance innovation capability through "carrot and stick".

\section{B. Innovation Capability Index}

There are many indexes to evaluate innovation capability, such as the increase of new high-tech product, the number of published journal, the number of patent application, the number of patent granted, the sales revenue of new products 
and so on. This paper chooses innovation input capability and innovation output capability to evaluate innovation capability. In terms of innovation input, we choose R\&D expenditure as the index of evaluating innovation input. R\&D is the source of technological innovation. Every county spare no effort to increase research funds in order to strengthening science \& technology and sustainable development capacity. Therefore, the investment of R\&D expenditure can reflect the country's innovation activity intensity. In terms of innovation output, we choose the number of patent application as the index of evaluating innovation output. Compared with the number of patent granted, the number of patent application is little affected by patent agency's work efficiency and preference, so the number of patent application is a better index to evaluate innovation output capability.

\section{Evaluation Index System}

Combined with the analysis of informatization and innovation capability, as well as, based on the purpose of enhancing innovation capability and increasing social economy benefit, we construct the index system of informatization affects innovation capability(two variables, four secondary indexes, six third class indexes), as shown in "Table I".

TABLE I. Index system of informatization affects innovation capability

\begin{tabular}{|c|c|c|c|}
\hline Variable & $\begin{array}{l}\text { Secondary } \\
\text { Index }\end{array}$ & $\begin{array}{l}\text { Third Class } \\
\text { Index }\end{array}$ & Explain of The Index \\
\hline \multirow{4}{*}{$\begin{array}{l}\text { Informatiz } \\
\text { ation }\end{array}$} & \multirow[b]{2}{*}{$\begin{array}{l}\text { hard } \\
\text { information } \\
\text { environment }\end{array}$} & $\begin{array}{l}\text { The sate of } \\
\text { informatization } \\
\text { development } X_{1}\end{array}$ & $\begin{array}{l}\text { The increased value of } \\
\text { information industry } \\
\text { accounts for the proportion } \\
\text { of GDP }\end{array}$ \\
\hline & & $\begin{array}{l}\text { The state of } \\
\text { informatization } \\
\text { human } \\
\text { resource } \mathrm{X}_{2}\end{array}$ & $\begin{array}{l}\text { the number of information } \\
\text { industry employees } \\
\text { accounts for the proportion } \\
\text { of employees in the whole } \\
\text { society }\end{array}$ \\
\hline & \multirow{2}{*}{$\begin{array}{l}\text { soft } \\
\text { information } \\
\text { environment }\end{array}$} & $\begin{array}{l}\text { The state of } \\
\text { information } \\
\text { consumption } \\
\mathrm{X}_{3}\end{array}$ & $\begin{array}{l}\text { Information consumption } \\
\text { coefficient }\end{array}$ \\
\hline & & $\begin{array}{l}\text { The } \\
\text { popularization } \\
\text { and application } \\
\text { of information } \\
\text { technology } \mathrm{X}_{4}\end{array}$ & $\begin{array}{l}\text { Internet users per million } \\
\text { people }\end{array}$ \\
\hline \multirow{2}{*}{$\begin{array}{l}\text { Innovation } \\
\text { Capability }\end{array}$} & $\begin{array}{l}\text { innovation } \\
\text { input } \\
\text { capability }\end{array}$ & $\begin{array}{l}\text { the investment } \\
\text { of } R \& D \\
\text { expenditure } \mathrm{Y}_{1}\end{array}$ & $\mathrm{R} \& \mathrm{D}$ expenditure \\
\hline & $\begin{array}{l}\text { innovation } \\
\text { output } \\
\text { capability }\end{array}$ & $\begin{array}{l}\text { The state of } \\
\text { patent } \\
\text { application } Y_{2}\end{array}$ & $\begin{array}{l}\text { The number of patent } \\
\text { application }\end{array}$ \\
\hline
\end{tabular}

\section{RESEARCH METHOD AND MODEL BUILDING}

\section{A. Research Method}

Data Envelopment Analysis is proposed by American famous operations researchers $\mathrm{A}$. Charnes and W. W. Cooper. It has been used in various industries and departments, and reflected excellent advantages in dealing with multiple input and output indicators. In recent years, DEA is a method which is widely applied in management evaluation. This paper mainly study the effect of the informatization on innovation capability. We choose some related informatization and innovation capability indexes to use DEA method, so explained variables are the efficiency value calculated by DEA and explaining variables are informatization and innovation capability indexes, then use multiple regression analysis and get rid of unreasonable variables, and so forth, until the whole system reach relatively stable.

Compared with other multi-objective evaluation methods, DEA has many advantages: when using DEA, we could not consider dimension, but other methods have to do so. And when using other evaluation methods, we should determine the relative weight of the indexes in advance and the function relation between input and output of decision making units, but DEA shouldn't. Therefore, the advantages of DEA is excluding many subjective factors and simplifying problems, that is, heightening objectivity of evaluating conclusions.

\section{B. Model Building}

Regression analysis generally refers to the calculation method or theory which is the correlation of one variable relative to other variables. It can calculate the overall average of the explained variable according to the given explaining variable.

The traditional multiple regression model:

$\ln \mathrm{y}=\mathrm{a}+\mathrm{c}_{1} \ln \mathrm{x}_{1}+\mathrm{c}_{2} \ln \mathrm{x}_{2}+\ldots \ldots+\mathrm{c}_{\mathrm{n}} \ln \mathrm{x}_{\mathrm{n}}$

Thereinto, $\mathrm{a}$ is constant, $\mathrm{y}$ is explained variable, $\mathrm{x}_{1}$ 、 $\mathrm{x}_{2}, \ldots \ldots, \mathrm{x}_{\mathrm{n}}$ are explaining variables, $\mathrm{c}_{1}, \mathrm{c}_{2}, \ldots \ldots, \mathrm{c}_{\mathrm{n}}$ are coefficients.

Optimizing the DEA variables, and we can view DEA efficiency value as explained variables and view informatization and innovation capability variables as explaining variables, building the model as shown below:

$\ln \mathrm{E}=\mathrm{a}+\mathrm{c}_{1} \ln \mathrm{x}_{1}+\mathrm{c}_{2} \ln \mathrm{x}_{2}+\ldots+\mathrm{c}_{\mathrm{n}} \ln \mathrm{x}_{\mathrm{n}}+\mathrm{d}_{1} \ln \mathrm{y}_{1}+\mathrm{d}_{2} \ln \mathrm{y}_{2}+\ldots+\mathrm{d}_{\mathrm{n}} \ln \mathrm{y}_{\mathrm{n}}$

thereinto, $\mathrm{E}$ is DEA efficiency value, $\mathrm{x}_{1}, \mathrm{x}_{2}, \ldots \ldots, \mathrm{x}_{\mathrm{n}}$ are informatization variables, $\mathrm{y}_{1}, \mathrm{y}_{2}, \ldots \ldots, \mathrm{y}_{\mathrm{n}}$ are innovation capability variables, $\mathrm{c}_{1}, \mathrm{c}_{2}, \ldots \ldots, \mathrm{c}_{\mathrm{n}}$ and $\mathrm{d}_{1}, \mathrm{~d}_{2}, \ldots . ., \mathrm{d}_{\mathrm{n}}$ are coefficients, a is constant.

This paper's calculated thought is: first use DEA to calculate the efficiency, and then do regression analysis, so the method can be called a efficiency and regression model.

\section{Model CAlculation}

\section{A. Data Selection}

This article selected data form2009 to 2013, at the same time, considering the time lag that the effect of informatization on innovation capability, so when we doing the research, we set the time lag for 3 years. The data comes from the yearbook of China Statistical and the yearbook of science and technology of China and CNNIC reports. 


\section{B. Model Calculation and Analysis}

In this paper, the steps of applying model to calculate are: first use DEAP software to analyze the efficiency of each index data, then use the efficiency value as explained variable, using SPSS software for multiple regression analysis, finally come to the conclusion. Before efficiency and regression analysis, we should do descriptive statistical analysis. The result of descriptive statistical analysis is shown in "Table II", and the result of correlation analysis is shown in "Table III".

TABLE II. DESCRIPTIVE STATISTICAL ANALYSIS

\begin{tabular}{|c|c|c|c|c|c|c|}
\hline Variable & Secondary Index & Third Class Index & Minimum & Maximum & Average & Standard Deviation \\
\hline \multirow{4}{*}{ Informatization } & \multirow{2}{*}{$\begin{array}{l}\text { hard information } \\
\text { environment }\end{array}$} & The sate of informatization development $\mathrm{X}_{1}$ & 0.7930 & 0.9594 & 0.8855 & 0.0635 \\
\hline & & The state of informatization human resource $X_{2}$ & 0.1655 & 0.3507 & 0.2663 & 0.0746 \\
\hline & \multirow{2}{*}{$\begin{array}{l}\text { Soft information } \\
\text { environment }\end{array}$} & The state of information consumption $\mathrm{X}_{3}$ & 3.1329 & 3.2288 & 3.1913 & 0.0375 \\
\hline & & $\begin{array}{l}\text { The popularization and application of } \\
\text { information technology } \mathrm{X}_{4}\end{array}$ & 4.9200 & 6.1253 & 5.6080 & 0.4833 \\
\hline \multirow{2}{*}{$\begin{array}{l}\text { Innovation } \\
\text { capability }\end{array}$} & $\begin{array}{l}\text { innovation input } \\
\text { capability }\end{array}$ & the investment of $R \& D$ expenditure $Y_{1}$ & 8.6660 & 9.3798 & 9.0435 & 0.2861 \\
\hline & $\begin{array}{l}\text { innovation output } \\
\text { capability }\end{array}$ & The state of patent application $\mathrm{Y}_{2}$ & 4.4746 & 5.3392 & 4.9179 & 0.3629 \\
\hline
\end{tabular}

TABLE III. CORRELATION ANALYSIS

\begin{tabular}{|c|c|c|c|c|c|c|c|}
\hline & & $X_{1}$ & $\mathbf{X}_{2}$ & $\mathbf{X}_{3}$ & $\mathbf{X}_{1}$ & $Y_{1}$ & $\mathbf{Y}_{0}$ \\
\hline \multirow[b]{2}{*}{$\mathbf{X}_{1}$} & Pearson correlation & 1 & -0.643 & -0.492 & -0.594 & $0.636^{\text {** }}$ & $0.614^{\text {** }}$ \\
\hline & Significance (two-sided) & & 0.242 & 0.435 & 0.291 & 0.002 & 0.000 \\
\hline \multirow[b]{2}{*}{$\mathbf{X}_{2}$} & Pearson correlation & -0.643 & 1 & -0.304 & 0.453 & $0.999^{* * \pi}$ & $0.993^{* * *}$ \\
\hline & Significance (two-sided) & 0.242 & & 0.619 & 0.221 & 0.000 & 0.001 \\
\hline \multirow[b]{2}{*}{$\mathbf{X}_{3}$} & Pearson correlation & -0.492 & -0.304 & 1 & -0.377 & $0.732^{* *}$ & $0.598^{* *}$ \\
\hline & Significance (two-sided) & 0.435 & 0.619 & & 0.531 & 0.005 & 0.000 \\
\hline \multirow[b]{2}{*}{$\mathbf{X}_{4}$} & Pearson correlation & -0.594 & 0.453 & -0.377 & 1 & $0.643^{* *}$ & $0.731^{\text {*** }}$ \\
\hline & Significance (two-sided) & 0.291 & 0.221 & 0.531 & & 0.000 & 0.002 \\
\hline \multirow[b]{2}{*}{ Y1 } & Pearson correlation & $0.636^{* * *}$ & $0.999 * *$ & $0.732 * *$ & $0.643 * *$ & 1 & $0.996 * *$ \\
\hline & Significance (two-sided) & 0.002 & 0.000 & 0.005 & 0.000 & & 0.000 \\
\hline \multirow[b]{2}{*}{ Y2 } & Pearson correlation & $0.614 * *$ & $0.993 * *$ & $0.598 * *$ & $0.731 * *$ & $0.996^{* * *}$ & 1 \\
\hline & Significance (two-sided) & 0.000 & 0.001 & 0.000 & 0.002 & 0.000 & \\
\hline
\end{tabular}

First, we should input the data to DEA model, and do the efficiency analysis. Then, use the efficiency value as the explained variable to do multiple regression analysis. According to the result of regression, get rid of the failed indexes by t-test. Once again, do the efficiency analysis and regression analysis, and so forth, until all the indexes pass the test. Finally, we can come to the conclusion and summary the calculated result. As shown in "Table IV".

TABLE IV. STATISTICAL MODEL CALCULATION RESULTS

\begin{tabular}{|c|l|l|l|}
\hline Variable & \multicolumn{1}{|c|}{ Efficiency $\mathbf{1}$} & \multicolumn{1}{|c|}{ Efficiency 2} & Efficiency 3 \\
\hline \multirow{2}{*}{ Constant a } & $-0.6873^{* *}$ & $-0.7628^{* *}$ & $-1.3247^{* *}$ \\
& $(-2.9342)$ & $(-3.0946)$ & $(-3.1134)$ \\
\hline \multirow{2}{*}{$\mathrm{X}_{1}$} & $0.8261^{* *}$ & $0.3265^{* *}$ & $0.2364^{* *}$ \\
& $(2.7979)$ & $(1.8775)$ & $(4.4750)$ \\
\hline $\mathrm{X}_{2}$ & $0.8203^{* *}$ & $0.9564^{* *}$ & $0.7894^{* *}$ \\
& $(-1.7892)$ & $(-2.0312)$ & $(-2.3612)$ \\
\hline $\mathrm{X}_{3}$ & $0.4532^{* *}$ & $0.8510^{* *}$ & $0.7833^{* * *}$ \\
& $(2.7865)$ & $(1.0982)$ & $(1.4976)$ \\
\hline $\mathrm{X}_{4}$ & 0.1463 & - & \\
\hline \multirow{2}{*}{$\mathrm{Y}_{1}$} & $(0.3221)$ & & \\
\hline $\mathrm{Y}_{2}$ & $0.3285^{*}$ & 0.6435 & - \\
\hline $\mathrm{R}^{2}$ & $(2.5568)$ & $(-0.3367)$ & \\
\hline $\mathrm{Wh}^{2}$ & $(-1.4226)$ & $0.4850^{*}$ & $0.6752^{*}$ \\
$(2.3412)$ & $(2.4431)$ \\
\hline
\end{tabular}

When doing the first efficiency and regression analysis, the three variables of the state of informatization development and informatization human resource and information consumption pass t-test in the percent of ten, but the index of popularization and application of information technology don't, so we should make further adjustment.

When doing the second efficiency and regression analysis, we should get rid of the variable of popularization and application of information technology and choose $X_{1}-X_{3}$ as informatization variables and choose $Y_{1}-Y_{2}$ as innovation capability variables and do the efficiency analysis. Then, view the calculated efficiency value as explained variables and plug the rest five variables into model 2 and then do the multiple regression analysis. The result of calculating is shown in "Table IV". As we can seen from the efficiency 2 line in "Table IV", its $\mathrm{R}^{2}$ is 0.8324 , so the model result is relatively stable. We can conclude that the state of informatization development and informatization human resource and information consumption and patent application pass t-test in the percent of ten, but the investment of $R \& D$ expenditure don't, so we should make further adjustment.

When doing the thrid efficiency and regression analysis, we should get rid of the variable of the investment of $R \& D$ expenditure and choose $\mathrm{X}_{1}-\mathrm{X}_{3}$ as informatization variables and choose $Y_{2}$ as innovation capability variable and do the efficiency analysis. Then, view the calculated efficiency value as explained variables and plug the rest four variables into model 2 and then do the multiple regression analysis. 
The result of calculating is shown in "Table IV". As we can seen from the efficiency 3 line in "Table IV", its $\mathrm{R}^{2}$ is 0.8677 , so the model result is relatively stable. We can conclude that the state of informatization development and informatization human resource and information consumption and patent application pass t-test in the percent of ten, so we finish the model adjustment.

In this paper, we analyze the effect of informatization on innovation capability by using the efficiency and regression model, and the situation where $\mathrm{R}^{2}$ is too small or efficiency is too low didn't appear. It is illustrate that the efficiency and regression model of the effect of informatization on innovation capability don't have structural errors, so the model is relatively stable.

\section{CONCLUSION}

According to the result of last chapter's efficiency and regression model, among the four informatization indexes, the sate of informatization development, informatization human resource and information consumption have obvious effect on innovation capability. However, the popularization and application of information technology hasn't obvious effect on innovation capability. The reason may be that the index's time lag may longer, but our research's time lag shorter and can't reflect its effect on innovation capability. And another reason is that the popularization and application of information technology only has significant effect on people's daily life, but hasn't widely effect in production development area.

On the basis of above analysis, we can draw the conclusion that informatization construction has significant effect on innovation capability. Therefore, both enterprises and country should attach importance to the informatization construction. Because informationization can enhance independent innovation capability, and then improve the ability of enterprise development and the national economic strength.

\section{REFERENCES}

[1] Beneito P.The innovative performance of in-house and contracted $\mathrm{R} \& \mathrm{D}$ in term of patents and utility models[J].Research Policy,2006,35:502-517.

[2] Hua M C,Mathews J A.China's national innovative capacity[J].Research Policy,2008,37(9):1465-1479.

[3] Wei Y,Q Wang.Making Sense of a Market Information System for Superior Performance:The Roles or Organizational Responsiveness and Innovation Strategy[J].Industrial Marketing Management,2010,40(2):267-277.

[4] Bose R,X Luo.Integrative Framework for Assessing Firms' Potential to Undertake Green IT Initiatives via Virtualization-A Theoretical Perpective[J].The Journal of Strategic Information Systems,2011,20(1):38-54.

[5] Forsman.H-Innovation Capacity and Innovation Development in Small Enterprises.A Comparison Between the Manufacturing and Service Sectors[J].Research Policy,2011,40(5),739-750.

[6] Bergfors,M.,Lager,T.Innovation of Process Technology:Exploring Determinants for Organizational Journal of Innovation Management,2011,(5).
[7] Lu, Y.,Ramamurthy,K.Understanding the Link Between Information Technology Capability and Empirical Examination[J].MIS Quarterly,2011,(4).

[8] Wang Jinzhou.Discussion on the Relationship between Green Technological Innovation and System Innovation.Energy Procedia,2011,5:2352-2357.

[9] Ding,J.H.,Chen,P.S.,Lyuc,J.J.Evolutionary Strategy to Apply Information and Communication Technology: A Case Study in the Apparel Industry[J].Production Planning \&Control:The Management of Operations,2011,(3).

[10] Castellacci F,Natera M J.The dynamics of national innovation systems:A panel cointegration analysis of the coevolution between innovative capability and absorptive capacity[J].Rearch Policy,2013,42(3):1-31. 